\title{
The penitentiary system in Spain
}

\section{The use of imprisonment, living conditions and rehabilitation}

\section{José Cid}

Criminologia Aplicada a la Penologia

Department of Political Science and Public Law

Universitat Autònoma de Barcelona

e-mail: Josep.Cid@uab.es

The final, definitive version of this paper has been published in Punishment \& Society,

7(2): 147-166, 2005, by SAGE Publications Ltd.

Available at http://dx.doi.org/10.1177/1462474505050439 


\section{INTRODUCTION}

This article examines how close the Spanish penitentiary system comes to fulfilling what I believe is the ideal role for the prison in the system of punishment. This ideal is based on three propositions:

a) Imprisonment should be used only in those cases where a more humane punishment cannot be imposed (imprisonment as a last resort) and should be limited its duration in accordance with humanitarian standards (limitation of the use of imprisonment).

b) Living conditions in prison should be as similar as possible to those of people living in freedom (normalisation of prison life).

c) It should be possible for prisoners, while serving their sentences, to participate in treatment programmes that facilitate their early reintegration into society (rehabilitation in prison).

The two last two propositions of this ideal have been clearly established by the Spanish Constitution. Article 25.2 of the Constitution states that a person sentenced to a term of imprisonment should enjoy the same basic rights as any other citizen, although that these rights may be limited, and that prison sentences should be directed towards reeducation and reintegration.

The ideal of limiting the use of imprisonment is not laid down expressly by the Constitution. However, the Constitutional Court has held that imprisonment should be reserved for those cases in which it is not possible to employ less intrusive methods for the protection of society (STC 161/1997). The Constitutional Court has also established the principle of proportionality as a limit to the duration of the penalty (STC 136/1999). 
These constitutional precepts are reflected in legislation -the Penitentiary Law of 1979 and the Penitentiary Rules of 1996- that applies throughout Spain. However legislation is implemented by two different penitentiary administrations, namely, the administration of Catalonia and General Administration of the State (GSA), which is responsible for prisons in the rest of Spain. Given that the legislation is open to different interpretations and degrees of compliance, the discussion below deals with both administrations.

\section{USE OF IMPRISONMENT}

The imprisonment rates and admissions to prison in recent years are reflected in the following tables:

\section{Insert}

[TABLE 1]

[TABLE 2]

Spain has one of the highest rates of imprisonment in the European Union: only those for Portugal and England \& Wales are higher (See data in Bulletin d'Information pénologique, 2000, No 22, page 61). In my opinion, the reason for the high imprisonment rates in Spain is mainly the severity of the prescribed penalties, which became harsher after the enactment of the 1995 Penal Code.

Before 1995 it was a feature of the Spanish penal system that the sanction for most of the offences, including the more frequent committed offences such as property and drug trafficking offences, was imprisonment. Moreover, judges were only allowed to suspend prison sentences of up to one year and then only when the offender had no previous 
criminal record. However, although sentences were generally longer than in other European Union countries, the time spent in prison could be reduced through good time credits, based on good behaviour and participation in treatment activities. This meant that offenders could be granted parole after having served between one third and one half of the sentence imposed by the judge.

With the current Penal Code the situation is that most of the offences ${ }^{i}$ continue to be sanctioned with imprisonment ${ }^{\mathrm{ii}}$ and the possibilities for suspending or substituting the sentence of imprisonment with a fine have been increased. Such suspension or substitution applies to prison sentences of up to two years, even when the person has a previous criminal record. However, even though the penalties for some of the offences have been reduced, a person must now serve generally three-quarters of a sentence to be eligible for release on parole.

The effect of the 1995 Penal Code has been paradoxical. Although, as shown in Table 2, the number of entries into prison has declined in recent years, this has not prevented the average number of people in prison from increasing. This leads to the conclusion that the slight reduction of punishment for some offences and the increase in the possibilities of suspending or substituting these prison sentences has not compensated for the increased period that must be served before parole is granted. The overall assessment, that the 1995 Penal Code of 1995 has resulted in a more punitive system, can also be demonstrated by the parole figures in Table 3, which show a reduction by a half between 1996-2003.

\section{Insert}

[TABLE 3] 
An evaluation of the Spanish penal system in the light the ideal of limitation of the use of imprisonment leads to the further conclusion that, despite the 1995 Penal Code's extension of suspension and substitution of prison sentences, many admissions to prison are still for less serious offences such minor crimes against property and minor drug trafficking offences. This reveals the legal and practical shortcomings of the system of alternatives to imprisonment enshrined in the 1995 Penal Code. ${ }^{\text {iii }}$ Moreover, the extension of the effective duration of sentences introduced by the CP of 1995 does not appear to be justified in terms of the doctrine of proportionality and, as we shall see, makes application of the constitutional principle of rehabilitation far more difficult too.

\section{LIVING CONDITIONS IN PRISON}

\section{Infrastructure}

There are 77 prisons in Spain, 35 of which were built before 1980, the remaining 42 being built after that date. There is no doubt that the modern buildings, which were mainly constructed in the 1990s, have clearly improved prisoners' living conditions (Defensor del Pueblo (Spanish Ombudsman) Informe 1997:194) and have avoided the overcrowding that the European Committee for prevention of Torture and Inhuman and Degrading Treatment or Punishment (CPT) described as inhumane (CPT, Visit report 10-22 April 1994, 129). The new prisons are modular, based on the cellular principle, and provide for the full range of services stipulated by legislation (workshops, sports and cultural facilities, sick bays, and others).

Although investment has also been made in the older prisons, until the proposed total renovation of all prisons is complete, there will continue to be considerable differences 
between conditions in the newer prisons and those in the older ones (Defensor del Pueblo, Informe 1999: 195).

An important issue is that the facilities for women are worse than those for men. This problem, which is particularly evident in the women's wings of old prisons for men, can be seen, for example, in the condition of the physical structures, in the greater scarcity of employment opportunities and in the narrower range of activities on offer (Defensor del Pueblo, Informe 1999: 219, Informe 2001:106).

\section{Accommodation}

The accommodation of prisoners raises a variety of issues. As for the place where a sentence is served is concerned, the construction of new prisons has allowed more people to serve their sentences in a prison near where the ordinarily live. Although there are no official figures available, the information given to the author indicates that, in the GSA territory $80 \%$ of prisoners serve their sentences in their community of residence and almost all prisoners resident in Catalonia serve their sentences in their own community. Obviously, for the still considerable percentage of people who, because of a lack of prison places in their own community, do not serve their sentences near where they ordinarily live, contact with family and friends is more difficult and the opportunities for reintegration are reduced. The Ombudsman has recommended that, in order to address this problem more effectively, a system of waiting lists should be established. This would provide a rational and fair basis for deciding on requests for a transfer (Defensor del Pueblo, Informe 1999:207).

A different problem is that of people who do not serve their sentences in their community of residence for reasons other than the lack of prison space in their own community. These include prisoners who are members of the terrorist organisation, ETA, 
who are dispersed throughout the GSA territory, and those who are subjected to punitive transfers. The practice of punitive transfers has been highly controversial. In this respect, the Ombudsman has recommended that the authorities should balance the need for a transfer with the problems generated by uprooting people (Defensor del Pueblo, Informe 1999: 206).

As for the separation of prisoners, current legislation states that the following categories of prisoners should be held separately: men and women, juveniles and adults, prisoners on remand and convicted prisoners, and first offenders and recidivists. The only one of these rules that is observed without exception is the separation of men and women. Juveniles and adults are not separated in the case of women: thus this group is discriminated, once again, in contrast to men. However, only in certain prisons are young men separated from older prisoners. Although there are remand prisons and other prisons for convicted prisoners, in reality most remand prisons also hold a section of the convicted population. Finally, although in certain prisons there might be a section for first offenders, the distinction between first offenders and recidivists is not generally observed in practice.

In prison, women with children under three years old have the right to be held in maternity wings. In the GSA territory, $15 \%$ of children are still not accommodated in such wings, but rather are housed in the ordinary wings for women prisoners (Defensor del Pueblo, Informe 2001:107).

As for sleeping accommodation, the penitentiary law states that prisoners should have individual cells, but in practice, leaving aside the case of some older prisons for whom accommodation is still in communal dormitories, in most prisons there are two people in each cell. As individual cells are important in guaranteeing the constitutional rights of prisoners, this practice has been repeatedly denounced by the Ombudsman and the CPT 
(Defensor del Pueblo, Informes 1997:93, 1998: 230, 1999:197 and CPT, Report, visit 10-22 April 1994, 131; Report visit 22 November-4 December 1998, 75-76). There is no doubt that the solution to this problem ${ }^{\text {iv }}$ needs to involve not only the Penitentiary Administration but also the legislator and the judges. However, it does not appear that the penitentiary administrations, neither in the GSA nor in Catalonia, consider accommodation in individual cells to be a priority.

During 2002 and 2003 there was a major increase in the prison population, which reached 130 inmates per 100.000 inhabitants thus breaking with the tendency, reflected in Table 1 for a moderate annual increase. This has revived the problem of overcrowding and has undoubtedly worsened the living conditions of prisoners (Defensor del Pueblo, Informe 2002:48)

\section{Health Care}

Health care is provided by penitentiary clinics, with the National Health Service providing a backup whenever further intervention is required. Thanks to investment in penitentiary clinics and the creation in the 1990s of units for those in custody within the public health network, evaluations undertaken by the control institutions (the Ombudsman and the CPT) of the health care given to prisoners are currently positive. It is considered that prison health care meets the ideal of "normalisation".

The most negative aspect of the health care system is in the treatment provided for the mentally ill. There are insufficient dedicated units capable of giving specific attention to such inmates. Other problems are the prevalence of pharmacological treatment over a more integrated approach to caring for mental illness and that fact that mentally ill prisoners are 
often abandoned after their release from prison (Defensor del Pueblo, Informe 1998: 233, Informe 2000:53).

Special mention must be given to the question of drug addicts in prison. Spain is one of the EU countries with the highest number of drug-addicted prisoners (See EMCDA 2001: 25-26). Both because so many intravenous drug users are admitted to prison and because of widespread intravenous drug use in prison without measures to avoid infection the number of HIV-positive prisoners in Spain is much higher than in any other EU country (EMCDA 2001:50).

The principle of normalisation requires that drug addicts in prison should have access to the same programmes for treatment and risk reduction that exist on the outside. Risk reduction programmes through the dispensation of methadone have been in place since the 1990s and are currently available in most Spanish prisons. Syringe exchanges have gradually been implemented since 1997, and have been extended to some of the prisons belonging to the GSA. In summary, even though health care for drug addicts has clearly improved with respect to that which existed in the early 1990 and the principle of normalisation is far more observed, it is reprehensible that risk reduction programmes have not been extended to all Spanish prisons. ${ }^{\mathrm{v}}$

\section{Work}

According to the Spanish Constitution, the right to work is one of the rights of those serving prison sentences. At the same time, penitentiary legislation states that prisoners have both a right and an obligation to work. But the reality is that the Spanish penitentiary system does not guarantee that every person wishing to work can actually do so. ${ }^{\mathrm{vi}}$ According to 1999 data, in the GSA territory the paid-work positions provided in 
workshops or in the services of the prison itself covered approximately $20 \%$ of the prison population (DGIP, Informe 1999). The scarcity of paid work and the poor remuneration for it, which is inadequate to satisfy the economic needs of the prisoners and of their families, is one of the most serious deficiencies of the Spanish penitentiary system (Defensor del Pueblo, Informe 1999, 205, Informe 2001:110).

\section{Communication with the outside world}

Penitentiary legislation establishes the right to communicate with the outside world by mail and telephone, to receive visits from family and friends, and, in the case of inmates not benefiting from temporary leave, to be able to maintain intimate communication with their partners and families. There do not appear to be problems with exercising these rights. The complaint by the Ombudsman, that some prisons did not possess adequate facilities for intimate visits (Defensor del Pueblo, Informe 1988-1996: 76), has not been repeated in recent years.

\section{Ill treatment}

The fact that the Spanish penitentiary system is subjected to external controls, the most important of which are the special judges who supervise administrative authorities (Juez de Vigilancia Penitenciaria), the Ombudsman (Defensor del Pueblo) and the CPT, seems to have played a decisive role throughout the 1990s, in reducing considerably prisoners' allegations of physical maltreatment by prison officers. This reached the point that the Ombudsman could speak some years ago of the "practically total eradication of physical mistreatment" (Defensor del Pueblo, Informe 1988-1996:36). Meanwhile, the CPT, which in its 1991 visit received many complaints of torture and ill treatment in the 
prisons it visited (CPT, Report, visit 1-12 April 1991, 91-98), received no complaints of torture during its 1998 visit and specified that the allegations of ill treatment referred only to those transferred to solitary confinement (CPT, Report, visit 22 November-4 December 1998, 54-56). It seems that the problem of ill treatment is currently confined mainly to cases of excessive force used by officers in those instances where prisoners have offered resistance.

However, it is important to treat the foregoing information with great caution, as, according to the Ombudsman, the decrease in reports of mistreatment in recent years is not due to a reduction in conflict. Rather it is the result of the absolute lack of inmate confidence in the Administration's ability to undertake impartial investigations (Informe 2001:102; Informe 2002:149). In fact, the Ombudsman has criticised the administration's ineffectiveness and lack of zeal in investigating reports of maltreatment (Defensor del Pueblo, Informe 1999: 214; Defensor del Pueblo, Informe 2000: 55).

From the perspective of humane treatment, we should also mention the situation of prisoners who serve their sentences in closed prison regimes. Two kinds of prisoners can be sent to a closed prison: those classed as being extremely dangerous and those who do not adapt to the ordinary prison regime. The former are sent to "special departments" (the most restrictive) and the latter to "closed departments". Table 4 shows that both in the GSA and in Catalonia, an average of $3 \%$ of prisoners served their sentences in a closed prison.

\section{Insert}

\section{[TABLE 4]}

The regime for prisoners in closed prisons, and in particular for those housed in "special departments", has been heavily criticised by the CPT, which considered that it could become similar to the situation of prisoners serving a sanction of solitary 
confinement in a cell (which lasts a maximum of 14 days) but without temporal limitation: it is legally possible for a person to serve the entire sentence in closed regime (CPT; visit 112 April 1991, 113).

The Spanish legislator accepted the recommendation of the CPT that the conditions of solitary confinement for persons serving in "special departments" had to be improved. In response, the 1996 Penal Code increased the time that could be spent outside the cell to a minimum of 3 hours.

However, both the Ombudsman (Informe 1999: 114) and the CPT in its report on its 1998 visit (Report Visit 1998: 68) indicate that people housed in "special departments" continue to suffer major isolation from prison staff; additionally, there are very few activities available. Taking into account the psychological deterioration and the increase in aggressiveness that long stays in these special departments produce (Defensor del Pueblo, Informe 1997:201), it seems necessary to improve living conditions for these prisoners by reducing hours of isolation, increasing association with other people, provision of more activities and even limiting the period of continuous stays in closed conditions.

\section{Legal protection of the prisoner}

The Constitution and the law guarantee prisoners' rights to makes complaints and to appeal against the decisions of the administration that they consider damaging to their rights or interests. There is a specialised jurisdiction to control the penitentiary administration and to protect the rights of prisoners (Juez de Vigilancia Penitenciaria). Moreover, prisoners can direct their requests and complaints to the public prosecutor and to the Ombudsman. In all these procedures, the prisoner has the right to a lawyer. 
All of these procedures aim to safeguard prisoners' rights against any illegal action carried out by the penitentiary administration. In practice, however, the legal protection of prisoners encounters certain difficulties. There is no provision for legal aid in penitentiary questions. Consequently, not all inmates are equally able to ensure the protection of their rights and interests. Moreover, penitentiary judges, have been criticised in certain cases for failing to act as guarantors of the rights of prisoners (Defensor del Pueblo, Informe 19881996:179; CPT, Report, Visit 10-22 April 1994, 185).

\section{REHABILITATION}

\section{Constitutional and legal framework}

Article 25.2 of the Constitution establishes that prison sentences must be geared towards re-education and reintegration. Although the concepts of re-education and reintegration are controversial, it seems, according to Mapelli (1983:150-152), that reeducation should be understood as activity aimed at fighting the causes of delinquency and preventing from recidivism, while reintegration consists of reincorporating offenders into society while they are serving their sentences. Therefore, in the context of the Spanish Constitution, it seems that rehabilitation should be conceptualised as the offender, who is re-educated or is in the process of re-education, being reintegrated into the community while serving a prison sentence. ${ }^{\mathrm{vii}}$

Following article 25.2 of the Constitution, penitentiary legislation establishes that a person serving a prison sentence has the right to receive or participate in treatment activities that should be offered by the penitentiary institution, such as education, professional training, work and specific treatment programmes. Moreover, also following article 25.2, legislation 
has created different mechanisms for the reintegration of the person in society while serving a prison sentence.

The most important of these mechanisms are, first, temporary leave, which allows a person serving a prison sentence in an ordinary prison regime to be temporarily released for periods of up to seven days and up to a total of 36 days a year. In order to benefit from temporary leave, inmates must have served a quarter of their sentence.

Secondly, the sentence may be served under an open prison regime. The open system is divided into two types: ordinary and restricted. The ordinary mode entails the prisoner spending a few hours a day outside an open prison, working or performing treatment related tasks, and having leave at weekends. In the restricted mode the prisoner only benefits from weekend leave. A prisoner must normally have completed a quarter of the sentence before being considered for open conditions.

The third mechanism is conditional release on parole, which entails release under supervision and assistance from the penitentiary administration. But supervision during parole seems to be very limited (VEGA 2001:360). Parole requires both the completion of three-quarters of the sentence, or two-thirds in exceptional cases, ${ }^{\text {viii }}$ and prior referral to an open regime.

In accordance with the constitutional concept of rehabilitation, for prisoners to benefit from these mechanisms their re-education prognosis must be positive, which can be shown through participation in treatment activities organised by the penitentiary administration.

\section{Treatment programmes}


It is worth distinguishing between generic programmes, designed to ensure that prisoners can spend their time in prison productively involved in work, education, training, sport and cultural activities, and specific programmes that are aimed at directly tackling some individual causes of criminal behaviour

With respect to generic programmes, it could generally be said that the prisoners, except when they are held under a closed regime, have the option of participating to a certain extent in all these programmes. Work is an exception, for, as was shown earlier, in Spanish prisons productive work is only available to approximately $20 \%$ of the prison population.

With respect to the generic treatment programmes, it is important to note that foreign prisoners with no legal standing in Spain, who constitute over the $20 \%$ of the prison population, have very restricted opportunities for rehabilitation. On the one hand, they cannot take part in the professional training courses, which tend to be financed by the European Union and which are only open to legal residents of a European Union country. On the other hand, as they have no right to work in Spain, it is more difficult for them to be admitted to an open prison.

As for specific treatment programmes it must be pointed out that these exist exclusively in two areas: treatment for drug-addict prisoners, and cognitive-behavioural programmes for offenders sentenced for violent crimes.

Programmes for treating drug-addict prisoners can either be followed under therapeutic community conditions at a penitentiary institution, or in extra-penitentiary institutions. These programmes combine medical treatment with psychological help and socio-labour therapy. The current demand for places on these programmes is far greater than what is on offer. 
For violent offenders there are generic programmes and specific programmes for sex offenders and those sentenced for domestic violence. While the programme for sex offenders, which began in 1997, exists in most Spanish prisons, the programmes for domestic offenders, which began in 1999, are only available in a few prisons within the GSA territory; the generic programmes for violent delinquents, which began in 2001, are only available in Catalonia. There are many more people in prison for violent offences than there are places on these programmes. Nevertheless, the information we have received from the administrators is that demand is not much greater than supply. Therefore, everybody wishing to participate in these programmes can do so at some point in their sentence.

One of the problems that penitentiary administrations have not solved is the continuity of these programmes once the person moves on to an open prison or is released on parole. There are no public or private institutions offering rehabilitation programmes for violent delinquents, making the extension of these programmes a difficult task.

\section{The general penitentiary system and that in Catalonia: comparative results}

Since the Spanish Constitution states that prison sentences should facilitate reeducation and reintegration, it seems that one criterion that could be used to measure the effectiveness of the penitentiary system is the number of people that manage to rehabilitate themselves. An indication of rehabilitation is being granted temporary leave and, most of all, being transferred to an open prison being granted parole.

Temporary leave, transfer to an open prisons and parole share, at least in theory, the two constitutional dimensions of rehabilitation: on the one hand, the person must have a positive prognosis for re-education for these to be granted (and the offender must behave in 
accordance with this prediction to avoid revocation), and, on the other hand, all of these institutions imply reincorporating the offender into the community.

In the following comments, I refer in particular to the results of the Spanish penitentiary system regarding the two institutions, which are deemed to have the greatest rehabilitative power: open prison and parole. However, before detailing the results, I should like to respond to a potential objection to the criterion for measuring rehabilitation that I am suggesting. It is quite reasonable to deny that the application of open prisons and parole can be considered a good criterion for measuring the level of rehabilitation produced by the penitentiary system, as it could be said that rehabilitation should be verified by not reoffending once the sentence has been served. I have no intention of challenging this as a good criterion for measuring rehabilitation, but given that, in the context of the Spanish Constitution, rehabilitation should be a goal achieved while serving the sentence, it seems reasonable to evaluate the penitentiary system from such a perspective. Moreover, criminological research seems to confirm that people serving part of their sentence in an open prison or on parole tend to reoffend less often than those serving their sentences in the ordinary system or those not granted parole (Redondo-Funes-Luque (1996:144-150). This suggests that the greater the percentage of people in open prisons or on parole, the better the chances for the penitentiary system to improve its results during the post-sentence period. ${ }^{\text {ix }}$

To evaluate the results of the Spanish penitentiary system, I shall now proceed by comparing the use made in the GSA and in Catalonia of open prisons and parole. 
Tables 5 and 6 reflect the use made in the GSA territory and Catalonia of open prisons, distinguishing the two modalities outlined by legislation. These are ordinary open prisons, where convicts spend a few hours a day outside the penitentiary building, working or performing rehabilitation-related tasks, and also have leave at weekends, and restricted open prisons, where prisoners benefit only from weekend leave.

\section{Insert}

\section{[TABLE 5]}

\section{[TABLE 6]}

It can be concluded from an analysis of Tables 5 and 6 that, with respect to open prison, the effectiveness of the Catalan penitentiary system is greater than that of the GSA. This is particularly evident if we compare the percentages of people in ordinary open prison regimes, from which it can most clearly be deduced that that they are rehabilitated, given that most of their activities takes place in the community. For such regimes the figures for Catalonia are almost triple those for the General State Administration.

What are the reasons for the Catalan administration achieving better results than the GSA administration with respect to the number of people serving in an open prison? As a working hypothesis, I would suggest the following:

(i) First, it could be relevant that the Catalan penitentiary system grants temporary leave more often to prisoners than the General State Administration, as is shown in Tables 7 and 8.

\section{Insert}

[TABLE 7]

[TABLE 8] 
The fact that in the period from 1996 to 2003 the Catalan penitentiary administration granted $40 \%$ more temporary leave than the GSA could be a relevant factor. This is because, in practice, it is a prerequisite for transferring a prisoner to an open prison that the prisoner has been granted temporary leave while in an ordinary prison and that such leave has been completed without negative incidents having occurred. Successful completion of temporary leave is an indicator of a prisoner's capacity for living in freedom without committing crimes. It is important to point out that, despite the granting of much more temporary leave by the Catalan administration, the data on failure to return to prison after such leave indicates that such failures are only $10 \%$ more frequent in Catalonia.

(ii) The second factor that could be relevant to understanding the difference between the percentages of open prisoners in the two administrations is that the Catalan administration has more professionals such as psychologists, criminologists, educators and social workers in its prisons. This means that reports needed to justify transfer to open institutions can be generated more quickly. Moreover, in Catalonia there is a specific service, which does not exist in the GSA, to assist prisoners who cannot do so themselves to find work. This service, which directly manages work seeking through agreements with collaborating businesses and which advises prisoners on ways of finding work, makes it easier for sentenced prisoners to be transferred to an open prison.

(iii) Finally, it may also be important that while prisoners resident in Catalonia serve their sentences in Catalan prisons, in the rest of Spain the percentage of people serving sentences in their autonomous community is only $80 \%$. Clearly, the possibility of being granted a temporary leave and of finding work is less when serving a prison sentence far from the usual place of residence. 


\section{Parole}

Tables 9 and 10 show the grants of parole by the GSA and by the Catalan administration.

\section{Insert}

[TABLE 9]

\section{[TABLE 10]}

Two aspects of these tables require further comment:

(i) Both in the GSA and in the Catalan administration, grants of parole were reduced by at least a half in the 1996-2003 period. This is due to the fact that the 1995 Penal Code abolished remission of sentences - good time credits. This produced an increase in the length of the sentence to be served.

It may appear very strange that if transfer to an open regime is usually made as preparation of parole, the reduction of parole has not produced a similar decrease in the percentage of prisoners transferred to an open prison. The only possible explanation of this paradox is that prisoners are classified as suitable for an open regime more easily than before. It would therefore seem that the new legislation leads to prisoners being kept within this third degree of imprisonment, although for their positive development they could perfectly well be out on parole.

(ii) The Catalan penitentiary administration does not fulfil the goal of rehabilitation better than the GSA with respect to parole releases. On the contrary, an average of $30 \%$ more of the overall number of convicted prisoners are granted parole in the GSA territory, a statistically significant difference. How can the paradox that Catalonia has a larger percentage of prisoners in open regimes but grants parole to fewer prisoners than in the 
GSA territory be explained? The only possible answer is that the Catalan administration is more demanding than the General State Administration in granting parole, as it requires the person to demonstrate of their re-education, through a longer stay in the open regime.

\section{Evaluation of the results}

From the analysis that I have made of the use of open systems and parole by the GSA and the Catalan administration, the following conclusions on the effectiveness of rehabilitation can be drawn:

(i) From the point of view of the effectiveness of rehabilitation in the two administrations the data show contradictory results: Catalonia is much more successful in granting leave and transferring prisoners to open regimes, but the GSA grants parole to more prisoners than the Catalan administration.

(ii) These data indicate that the two administrations have different models of parole, this is, parole as a means of re-education and parole as automatic early release of prisoners who have served most of their sentence. The approach of the Catalan administration follows the first model more closely and the GSA the second. As a matter of principle, the first model can only be supported if it is more effective in preventing reoffending.

(iii) Considering that the Catalan administration is more committed to the ideal of rehabilitation and that that leads to the sentence being more severe in practice (although only in relation to parole), the question that has to be answered is whether the relationship between rehabilitation and severity is a contingency or a necessity. My hypothesis is that in Catalonia prisoners tend to spend more time than the necessary in the open regime. This is due to the rigid legal framework, in terms of which parole can only be granted after they have served three quarters or at least two thirds of their sentence. Within a more 
individualized legal system, parole could be granted earlier. With such a system, the results of the Catalan administration with respect to parole could improve. ${ }^{\mathrm{x}}$

\section{CONCLUSIONS}

The description of the Spanish penitentiary system can be summarised by the following points:

(i) The Spanish punitive system makes excessive use of the sentence of imprisonment. There are two primary reasons for this. First, many offenders are still being sent to prison for non-serious offences. Such offenders should be dealt with by means of community sentences (Cid-Larrauri 2002). Secondly, the effective duration of the sentences is, without any justification, longer than in most European Union countries (see a European comparison in Bulletin d'information pénologique, 2000, No 22).

(ii) As a result of the significant prison renovation programme in the 1990s, prison conditions have improved considerably over the past decade. From the point of view of the principle of "normalising" prison life, further steps should be taken: Within the GSA there should be a greater emphasis on ensuring that prisoners serve their sentences nearer their homes. The right of prisoners to a single cell should be respected. Fairly paid penitentiary work should be available to all. Free legal advice should be provided to indigent prisoners to assist them in penitentiary matters. Furthermore, conditions in centres for women should be similar to those in centres for men. The problem of overcrowding, that seemed solved in the 1990s, has recently reappeared and it threatens the advances of the past decade. 
(iii) In the 1990s, as a consequence of stricter controls on the penitentiary administration, accusations of torture seem to have been eliminated and cases of ill treatment seem now to be exceptional. However, the data should be treated with caution, given the Ombudsman's complaint that the General State Administration does not investigate adequately reports of mistreatment. The living conditions of prisoners in closed prisons have improved since the reform of the prison rules in 1996, but the conditions of solitary confinement in the "special departments" is still excessively severe and does not meet standards of humane treatment.

(iv) Based on a constitutional interpretation, a criterion for measuring the capacity for rehabilitation of the penitentiary system is the number of sentenced prisoners who benefit from temporary leave, open prison and parole during their sentence. The comparison made between the results for the General State Administration and the Catalan administration leads to the conclusion that the latter is more committed to rehabilitation in relation to leave and to open regimes, but the former grants parole to more prisoners. This contradictory results are possibly due to the fact that the GSA approaches parole more as a form of automatic early release than as a final step in the process of re-education.

(v) The legal framework does not support a practice based on rehabilitation. This ideal requires legal possibilities for reintegration into community of the people who are reeducated or in the process of re-education. Delaying parole until the completion of three quarters or two thirds of the sentence ${ }^{x i}$ has negative consequences for the principle of rehabilitation. It leads either to the open regime not being applied until that moment approaches and then to parole being granted as an automatic early release (as the GSA 
does), or prisoners who seem ready for parole being kept in an open regime (as the Catalan administration does).

\section{Acknowledgements}

For their valuable comments on an early version of this text, I thank Elena Larrauri, Beatriz Tébar and Daniel Varona. Eulalia Luque, Jesús Martínez and Virgilio Valero, helped me with the interpretation of the data. I express my gratitude to Dirk van Zyl Smit, who revised the paper in order to make it more understandable. Nevertheless, any errors or deficiencies in the information or appreciation are my own responsibility. This article forms part of the research project entitled "Protection of the victim and rehabilitation of delinquents in freedom" (BJU2001-2075).

\section{References}

- Ararteko (Ombudsman of the Basque Country) (1996) Situación de las cárceles en el País Vasco. Vitoria, Ararteko.

- Cid, J.and E. Larrauri (eds.) (2002) Jueces penales y penas en España. Valencia: Tirant lo blanch.

- Consejería de Justicia (Cataluña), Memòria (1996, 1997, 1998, 1999). Barcelona: Consejería de Justicia.

-Council of Europe, CPT (European Committee for the Prevention of Torture and Inhuman or degrading Punishment), Spain, Report to the Spanish Government on the Visit to Spain, 
visit 01/04/1991-12/04/1991; visit 10/04/1994-22/04/1994; visit 22/11/1998-04/12/1998 (in: http://www.cpt.coe.int/en/states/esp.htm)

- Defensor del Pueblo (Spanish Ombudsman), Informe anual (1996, 1997, 1998, 1999, 2000, 2001, 2002). Madrid: Cortes Generales.

- Defensor del Pueblo, Informe sobre la situación penitenciaria (1988-1996). Madrid: Cortes Generales.

- Dirección General de Instituciones Penitenciarias (DGIP), Informe (1996, 1997, 1998, 1999). Madrid: Ministerio del Interior.

- European Monitoring Centre for Drugs and Drugs Addiction (EMCDDA), (2001) An Overview Study: Assistance to Drug Users in European Union Prisons, Wimblendon, Cranstoun Drug Services Publishing.

- Mapelli, B. (1983) Principios fundamentales del sistema penitenciario español. Barcelona:Bosch

- Redondo, S. J. Funes and E. Luque (1996) Justícia penal i reincidència. Barcelona: Centro de Estudios Jurídicos y Formación Especializada.

- Síndic de Greuges (Catalan Ombusdman) Informe al Parlament (1996, 1997, 1998, 2000). Barcelona: Parlamento de Cataluña.

- Vega, M (2002) La libertad condicional en el derecho español. Madrid:Cívitas 
- Van Zyl Smit, D. and F. Dünkel (eds.) (2001) Imprisonment Today and Tomorrow.

International Perspectives on Prisoners' Rights and Prison Conditions, 2nd edition., The Hague: Kluwer. 
TABLE 1 Average Prison Population in Spain (1996-2003)

\begin{tabular}{|l|l|l|l|l|}
\hline & ON REMAND & CONVICTED & TOTAL & $\begin{array}{l}\text { Prisoners per } \\
100,000 \\
\text { inhabitants }\end{array}$ \\
\hline 1996 & $10,588(23.9 \%)$ & $33,724(76.1 \%)$ & 44,312 & 112 \\
\hline 1997 & $11,083(25.5 \%)$ & $33,370(74.5 \%)$ & 43,452 & 109 \\
\hline 1998 & $11,272(25.2 \%)$ & $33,475(74.8 \%)$ & 44,747 & 112 \\
\hline 1999 & $10,576(23.3 \%)$ & $34,830(76.7 \%)$ & 45,406 & 113 \\
\hline 2000 & $9,729(21.5 \%)$ & $35,580(78.5 \%)$ & 45,309 & 112 \\
\hline 2001 & $10,006(21.4 \%)$ & $36,588(78.6 \%)$ & 46,594 & 114 \\
\hline 2002 & $11,340(22.6 \%)$ & $38,769(77.4 \%)$ & 50.109 & 121 \\
\hline 2003 & $12.383(22.7 \%)$ & $42,082(77.3 \%)$ & 54.465 & 129 \\
\hline
\end{tabular}

SOURCE: Dirección General de Instituciones Penitenciarias (DGIP), Número de internos en los centros penitenciarios. Evolución semanal; Secretaría de Servicios penitenciarios, Rehabilitación y Justicia Juvenil, (SSPRJJ), Estadísticas semanales de población reclusa. For the Spanish population figures: Instituto Nacional de Estadística. 
TABLE 2 Prison Admissions in Spain (1996-2003)

\begin{tabular}{|l|l|l|}
\hline YEAR & Admissions & Admissions per 100,000 inhabitants \\
\hline 1996 & 51,568 & 130 \\
\hline 1997 & 55,739 & 140 \\
\hline 1998 & 53,521 & 134 \\
\hline 1999 & 47,598 & 118 \\
\hline 2000 & 41,569 & 101 \\
\hline 2001 & 41,359 & 101 \\
\hline 2002 & 41.768 & 101 \\
\hline 2003 & 40.491 & 96 \\
\hline
\end{tabular}

SOURCE: with respect to the General State Administration (GSA) data: DGIP, Estadística Penitenciaria. Boletín semestral, $\mathrm{n}^{\mathbf{0}}$ 2, Junio 2001 and, for the years 2001, 2002, 2003, information supplied to the author by DGIP; with respect to the data for Catalonia: information supplied to the author by the SSPRJJ. 
TABLE 3 Parole granted in Spain (1996-2003)

\begin{tabular}{|l|l|l|l|}
\hline YEAR & $\begin{array}{l}\text { CASES OF PAROLE } \\
\text { GRANTED AVERAGE CONVICTED }\end{array}$ & $\begin{array}{l}\text { PAROLE GRANTED PER } \\
100 \\
\text { PRISONERS }\end{array}$ \\
\hline 1996 & 8,684 & & 26 \\
\hline 1997 & 6,669 & 33,724 & 20 \\
\hline 1998 & 6,215 & 33,370 & 19 \\
\hline 1999 & 6,050 & 33,475 & 17 \\
\hline 2000 & 5,628 & 34,830 & 16 \\
\hline 2001 & 5,453 & 35,580 & 15 \\
\hline 2002 & 5.442 & 36,588 & 14 \\
\hline 2003 & 5.062 & 38,796 & 12 \\
\hline
\end{tabular}

SOURCE: information supplied to the author by DGIP and SSPRJJ 
TABLE 4 Classification of Sentenced Prisoners. General State Administration and Catalonia (1996-2003).

\begin{tabular}{|c|c|c|c|c|c|c|c|c|c|c|c|c|}
\hline & \multicolumn{3}{|c|}{ TOTAL CLASSIFIED } & \multicolumn{3}{|c|}{$\begin{array}{l}\text { CLOSED PRISON } \\
\text { (FIRST DEGREE) }\end{array}$} & \multicolumn{3}{|c|}{$\begin{array}{l}\text { ORDINARY PRISON } \\
\text { (SECOND DEGREE) }\end{array}$} & \multicolumn{3}{|c|}{$\begin{array}{l}\text { OPEN PRISON } \\
\text { (THIRD DEGREE) }\end{array}$} \\
\hline & GSA & CAT & TOTAL & GSA & CAT & TOTAL & GSA & CAT & TOT & GSA & CAT & TOT \\
\hline 1996 & 22,599 & 4,112 & 26,711 & $3 \%$ & $2.2 \%$ & $2.9 \%$ & $81.7 \%$ & $75.2 \%$ & $80.5 \%$ & $15.3 \%$ & $23.3 \%$ & $16.6 \%$ \\
\hline 1997 & 22,699 & 4,066 & 26,765 & $2.9 \%$ & $3.1 \%$ & $2.9 \%$ & $82.8 \%$ & $73.7 \%$ & $81.4 \%$ & $14.3 \%$ & $23.2 \%$ & $15.7 \%$ \\
\hline 1998 & 24,250 & 4,079 & 28,329 & $2.8 \%$ & $2.6 \%$ & $2.8 \%$ & $83.8 \%$ & $72 \%$ & $82.2 \%$ & $13.5 \%$ & $24.5 \%$ & $15 \%$ \\
\hline 1999 & 25,017 & 4,125 & 29,232 & $3.1 \%$ & $2.5 \%$ & $3 \%$ & $82.9 \%$ & $72.4 \%$ & $81.4 \%$ & $14 \%$ & $25.1 \%$ & $15.6 \%$ \\
\hline 2000 & 26,466 & 4,417 & 30,838 & $3 \%$ & $3 \%$ & $3 \%$ & $83.7 \%$ & $71.9 \%$ & $82 \%$ & $13.3 \%$ & $25.1 \%$ & $15 \%$ \\
\hline 2001 & 28,033 & 4,459 & 32,492 & $2.8 \%$ & $3.3 \%$ & $2.9 \%$ & $83.7 \%$ & $72.7 \%$ & $82.2 \%$ & $13.5 \%$ & $24 \%$ & $14.9 \%$ \\
\hline 2002 & 29,939 & 4,896 & 34,835 & $2.9 \%$ & $3.5 \%$ & $3 \%$ & $83.5 \%$ & $70.4 \%$ & $81.7 \%$ & $13.6 \%$ & $26.1 \%$ & $15.3 \%$ \\
\hline 2003 & 32.780 & 5,420 & 38,200 & $2.9 \%$ & $2.5 \%$ & $2.9 \%$ & $85.7 \%$ & $72.2 \%$ & $83.8 \%$ & $11.4 \%$ & $25.3 \%$ & $13.3 \%$ \\
\hline $\begin{array}{l}\text { AVER } \\
1996-2\end{array}$ & & & & $2.9 \%$ & $2.8 \%$ & $2.9 \%$ & $83.5 \%$ & $72.6 \%$ & $81.9 \%$ & $13.6 \%$ & $24.6 \%$ & $15.2 \%$ \\
\hline
\end{tabular}

SOURCE: DGIP, Estadística General Población Reclusa. Evolución mensual.; SSPRJJ, Estadísiticas semanales de población reclusa. Data on December $31^{\text {st }}$ of each year. 
TABLE 5 Sentenced Prisoners in Open Prison Regimes (Ordinary/Restricted). General State Administration (1996-2003)

\begin{tabular}{|c|c|c|c|c|}
\hline & $\begin{array}{l}\text { NUMBER } \\
\text { SENTENCED } \\
\text { PRISONERS } \\
\text { CLASSIFIED }\end{array}$ & $\begin{array}{l}\text { ORDINARY OPEN } \\
\text { PRISON REGIME } \\
\text { Number and } \\
\text { percentage of the } \\
\text { sentenced prisoners } \\
\text { classified }\end{array}$ & $\begin{array}{l}\text { RESTRICTED } \\
\text { OPEN PRISON } \\
\text { REGIME } \\
\text { Number } \\
\text { percentage of the } \\
\text { sentenced prisoners } \\
\text { classified }\end{array}$ & $\begin{array}{l}\text { TOTAL OPEN } \\
\text { PRISON REGIME } \\
\text { Number and } \\
\text { percentage of the } \\
\text { sentenced prisoner } \\
\text { classified }\end{array}$ \\
\hline 1996 & 22,599 & $1,559(6.9 \%)$ & $1,898(8.4 \%)$ & $3,457(15.3 \%)$ \\
\hline 1997 & 22,699 & $1,475(6.5 \%)$ & $1,748(7.7 \%)$ & $3,223(14.2 \%)$ \\
\hline 1998 & 24,250 & $1,600(6.6 \%)$ & $1,649(6.8 \%)$ & $3,249(13.4 \%)$ \\
\hline 1999 & 25,017 & $1,651(6.6 \%)$ & $1,751(7 \%)$ & $3,402(13.6 \%)$ \\
\hline 2000 & 26,466 & $1,800(6.8 \%)$ & $1,880(7.1 \%)$ & $3,680(13.9 \%)$ \\
\hline 2001 & 28,033 & $2,132(7.6 \%)$ & $1,640(5.9 \%)$ & $3,772(13.5 \%)$ \\
\hline 2002 & 29,939 & $2.345(7.8 \%)$ & $1,726(5.8 \%)$ & $4.071(13.6 \%)$ \\
\hline 2003 & 32,780 & $2.406(7.4 \%)$ & $1,316(4 \%)$ & $3.722(11.4 \%)$ \\
\hline $\begin{array}{l}\text { AVERAGE } \\
\text { 1996-2003 }\end{array}$ & & $7 \%$ & $6.6 \%$ & $13.6 \%$ \\
\hline
\end{tabular}

SOURCE: DGIP, Estadística General de Población penitenciaria, Evolución mensual. Data on December $31^{\text {st }}$ of each year. 
TABLE 6 Sentenced Prisoners in Open Prison Regimes (Ordinary/Restricted). Catalonia (1996-2003)

\begin{tabular}{|c|c|c|c|c|}
\hline & $\begin{array}{ll}\text { NUMBER } & \text { OF } \\
\text { SENTENCED } & \\
\text { PRISONERS } & \\
\text { CLASSIFIED } & \end{array}$ & $\begin{array}{l}\text { ORDINARY OPEN } \\
\text { PRISON REGIME } \\
\text { Number and } \\
\text { percentage of the } \\
\text { sentenced prisoner } \\
\text { classified }\end{array}$ & $\begin{array}{l}\text { RESTRICTED } \\
\text { OPEN PRISON } \\
\text { REGIME } \\
\text { Number } \\
\text { percentage of the } \\
\text { sentenced prisoners } \\
\text { classified }\end{array}$ & $\begin{array}{l}\text { TOTAL OPEN } \\
\text { PRISON REGIME } \\
\text { Number and } \\
\text { percentage of the } \\
\text { sentenced prisoners } \\
\text { classified }\end{array}$ \\
\hline 1996 & 4,112 & $563(13.7 \%)$ & $397(9.7 \%)$ & $960 \quad(23.4 \%)$ \\
\hline 1997 & 4,075 & $662(16.2 \%)$ & $290(7.1 \%)$ & $952 \quad(23.3 \%)$ \\
\hline 1998 & 4,079 & $781(19.1 \%)$ & $231(5.7 \%)$ & $1,012(24.8 \%)$ \\
\hline 1999 & 4,206 & $827(19.7 \%)$ & $206(4.9 \%)$ & $1,033(24.6 \%)$ \\
\hline 2000 & 4,417 & $837(18.9 \%)$ & $275(6.2 \%)$ & $1,112(25.1 \%)$ \\
\hline 2001 & 4,549 & $854(18.9 \%)$ & $233(5.1 \%)$ & $1,091(24 \%)$ \\
\hline 2002 & 4,892 & $1,056(21.6 \%)$ & $213(4.4 \%)$ & $1,269(26 \%)$ \\
\hline 2003 & 5.411 & $1,215(22.5 \%)$ & $165(3 \%)$ & $1,380(25.5 \%)$ \\
\hline $\begin{array}{l}\text { AVERAGE } \\
\text { 1996-2003 }\end{array}$ & & $18.8 \%$ & $5.8 \%$ & $24.6 \%$ \\
\hline
\end{tabular}

SOURCE: SSPRJJ, Estadísticas semanales de población reclusa. Data on December $31^{\text {st }}$ of each year. 
TABLE 7 Temporary Leave for Sentenced Prisoners Serving in an Ordinary Prison. General State Administration (1996-2003)

\begin{tabular}{|l|l|l|l|l|l|}
\hline & $\begin{array}{l}\text { No } \\
\text { TEMPORARY } \\
\text { LEAVE } \\
\text { GRANTED }\end{array}$ & $\begin{array}{l}\text { NUMBER OF } \\
\text { SENTENCED } \\
\text { PRISONERS IN } \\
\text { AN } \\
\text { ORDINARY } \\
\text { PRISON } \\
\text { XII) }\end{array}$ & $\begin{array}{l}\text { RATIO OF } \\
\text { TEMPORARY } \\
\text { LEAVE PER } \\
\text { PRISONER } \\
\text { (BY YEAR) }\end{array}$ & $\begin{array}{l}\text { No } \\
\text { FAILURES TO } \\
\text { RE-ENTRY }\end{array}$ & $\begin{array}{l}\text { PERCENTAGE } \\
\text { OF FAILURES } \\
\text { TO RE-ENTRY }\end{array}$ \\
\hline 1996 & 28,388 & 18,436 & $1.55: 1$ & 500 & $1.8 \%$ \\
\hline 1997 & 26,976 & 18,744 & $1.40: 1$ & 435 & $1.6 \%$ \\
\hline 1998 & 26,638 & 20,312 & $1.30: 1$ & 387 & $1.45 \%$ \\
\hline 2099 & 27,705 & 20,739 & $1.30: 1$ & 373 & $1.35 \%$ \\
\hline 2001 & 27,114 & 22,152 & $1.20: 1$ & 371 & $1.35 \%$ \\
\hline 2002 & 28,372 & 23,473 & $1.20: 1$ & 403 & $1.40 \%$ \\
\hline 2003 & 29,001 & 25,009 & $1.15: 1$ & 414 & $1.40 \%$ \\
\hline AVERAGE & 31,893 & 28,102 & $1.15: 1$ & 359 & $1.10 \%$ \\
$1996-2003$ & & & & & \\
\hline
\end{tabular}

SOURCE: DGIP, Informe $(1996,1997,1998,1999)$; and information supplied to the author by the DGIP (data of temporary leave in the years 2000, 2001, 2002, 2003). 
TABLE 8 Temporary Leave for Sentenced Prisoners Serving in an Ordinary Prison. Catalonia (1996-2003)

\begin{tabular}{|l|l|l|l|l|l|}
\hline & $\begin{array}{l}\text { No } \\
\text { TEMPORARY } \\
\text { LEAVE } \\
\text { GRANTED }\end{array}$ & $\begin{array}{l}\text { NUMBER OF } \\
\text { SENTENCED } \\
\text { PRISONERS IN } \\
\text { AN ORDINARY } \\
\text { PRISON (31-XII) }\end{array}$ & $\begin{array}{l}\text { RATIO OF } \\
\text { TEMPORARY } \\
\text { LEAV PER } \\
\text { PRISONERS } \\
\text { (BY YEAR) }\end{array}$ & $\begin{array}{l}\text { No } \\
\text { FAILURES TO } \\
\text { RE-ENTRY }\end{array}$ & $\begin{array}{l}\text { PERCENTAGE } \\
\text { OFAILURES } \\
\text { TO RE-ENTRY }\end{array}$ \\
\hline 1996 & 6,080 & 3,059 & $2: 1$ & 90 & $1.50 \%$ \\
\hline 1997 & 5,558 & 2,997 & $1.85: 1$ & 74 & $1.35 \%$ \\
\hline 1998 & 5,703 & 2,972 & $1.90: 1$ & 104 & $1.80 \%$ \\
\hline 1999 & 5,540 & 3,050 & $1.80: 1$ & 80 & $1.45 \%$ \\
\hline 2000 & 6,093 & 3176 & $1.90: 1$ & 99 & $1.60 \%$ \\
\hline 2001 & 5,726 & 3,221 & $1.80: 1$ & 97 & $1.70 \%$ \\
\hline 2002 & 6.344 & 3.445 & $1.85: 1$ & 101 & $1.25 \%$ \\
\hline $\begin{array}{l}\text { AVERAGE } \\
1996-2001\end{array}$ & 6.378 & 3.915 & $1.60: 1$ & 81 & $1.55 \%$ \\
\hline
\end{tabular}

SOURCE: Consejería de Justicia (Catalonia) Memòria (1996, 1997,1998 and 1999) and information supplied to the author by SSPRJJ (data for temporary leave in years 2000, 2001, 2002, 2003). 
TABLE 9 Parole Granted: General State Administration (1996-2003)

\begin{tabular}{|l|l|l|l|}
\hline YEAR & $\begin{array}{l}\text { CASES OF PAROLE } \\
\text { GRANTED }\end{array}$ & $\begin{array}{l}\text { AVERAGE SENTENCED } \\
\text { PRISONERS }\end{array}$ & $\begin{array}{l}\text { PAROLE GRANTED } \\
\text { PER 100 SENTENCED } \\
\text { PRISONERS }\end{array}$ \\
\hline 1996 & 7,607 & 28,825 & 26 \\
\hline 1997 & 5,777 & 27,464 & 21 \\
\hline 1998 & 5,426 & 28,627 & 19 \\
\hline 1999 & 5,340 & 29,964 & 18 \\
\hline 2000 & 5,017 & 30,561 & 16 \\
\hline 2001 & 4,869 & 31,501 & 14 \\
\hline 2002 & 4,980 & 33,336 & 15 \\
\hline 2003 & 4,580 & 36,258 & 13 \\
\hline AVERAGE & & & \\
$1996-2003$ & & & $18: 100$ \\
\hline
\end{tabular}

SOURCE: information supplied to the author by DGIP (paroles granted) and DGIP, Número de internos en los centros penitenciarios. Evolución semanal (average prison population). 
TABLE 10 Parole Granted: Catalonia (1996-2003)

\begin{tabular}{|l|l|l|l|}
\hline YEAR & $\begin{array}{l}\text { CASES OF PAROLE } \\
\text { GRANTED }\end{array}$ & $\begin{array}{l}\text { AVERAGE SENTENCED } \\
\text { PRISONERS }\end{array}$ & $\begin{array}{l}\text { PAROLE GRANTED } \\
\text { PER 100 SENTENCED } \\
\text { PRISONERS }\end{array}$ \\
\hline 1996 & 1077 & 4,889 & $22: 100$ \\
\hline 1997 & 919 & 4,906 & $19: 100$ \\
\hline 1998 & 789 & 4,848 & $16: 100$ \\
\hline 1999 & 710 & 4,866 & $15: 100$ \\
\hline 2000 & 611 & 5,019 & $12: 100$ \\
\hline 2001 & 584 & 5,087 & $11: 100$ \\
\hline 2002 & 462 & 5,433 & $8: 100$ \\
\hline 2003 & 482 & 5,824 & $8: 100$ \\
\hline $\begin{array}{l}\text { AVERAGE } \\
1996-2003\end{array}$ & & & $14: 100$ \\
\hline
\end{tabular}

SOURCE: Information supplied to the author by SSPRJJ (paroles granted) and (SSPRJJ), Estadísticas semanales de población reclusa. (average prison population).

${ }^{\mathrm{i}}$ I refer exclusively to those infringements described as offences (and which may, perhaps, correspond to the North-American "felonies"). The situation is different to that of infringements described as minor offences (which may correspond roughly to the NorthAmerican "misdemeanors") for which the main penalty is a fine and the maximum penalty is weekend imprisonment.

ii Spanish penal law establishes a minimum and a maximum sentence, within the limits of which judges exercise their discretion to determine the sentence. For example, the offence of theft (of a value exceeding $€ 300$ ) is punished with a sentence of 6 to 18 months in prison.

iii To illustrate this question, I shall refer to Cid-Larrauri (eds.) (2002), in which empirical research was presented on the implementation of alternatives to imprisonment prescribed by the Penal Code of 1995 . The research shows that these alternatives are relatively ineffective in avoiding imprisonment of offenders have not committed serious crimes but nevertheless have a criminal record. 
iv The Spanish Constitutional Court has not contributed to a solution, for in its 195/1995, FJ 3 decision it held that compulsory accommodation in collective cells is a necessary consequence of the prisoner's loss of freedom. In contrast to this, however, the Supreme Court of Lower Saxony, Germany, has ruled that prisoners have a constitutional right to be housed in single cells (see: Dünkel-Rossner, in Van Zyl Smit- Dünkel 2001:312).

$\mathrm{v}$ I am referring to the exchange of syringes that has not yet been fully adopted in Catalonia, apparently due to pressure from prison unions that fear for the safety of prison officers. However, the experience of syringe exchange in the GSA territory does not seem to have generated any increase in security problems (DGIP, Informe 1998:135).

${ }^{\text {vi }}$ Constitutional jurisprudence has not contributed to the recognition of a general right to work. The Constitutional Court, in its decision 172/1989, FJ 3, established that the "right" to work is to be introduced gradually and that it only obliges the penitentiary administration to act within the limits of its resources. A counterexample can be observed in the Netherlands, where prison work is both a right and an obligation of all prisoners. In that the administration is obliged to provide paid work for prisoners and to pay them when it is unable to provide work (see Kelk, in Van Zyl Smit-Dünkel, 2001:495).

${ }^{\text {vii }}$ My reflections on the constitutional concept of rehabilitation were produced with the help of Beatriz Tébar, who defends this idea in her doctoral dissertation "La libertad condicional en el derecho español" (Barcelona, 2001), unpublished.

viii The criminal law establishes that parole may be also granted after two thirds of the sentence in cases where a prisoner participates in treatment activities for a long period. During the past three years $(2001,2002,2003)$ in the GSA territory parole has been granted 
after two thirds of a sentence has been served in $32 \%$ of the cases (information supplied to the author by the DGIP).

${ }^{\text {ix }}$ I make this claim with some hesitation, for in Spain there is no research comparing the recidivism rates of offenders who have benefited from the open system or parole with those for homogenous control groups that have not been granted those privileges. There is therefore always the possibility that the lower recidivism rate of offenders in the open system and on parole could be attributed exclusively to better personal circumstances which influenced the transfer to an open prison or the granting of parole and not to the specific manner in which the sentence has been served.

x A recent reform of the Penitentiary Law (L.O 7/2003) has include a new benefit, consisting in three months of remission for every year of time served, if offenders participate in treatment activities or in programmes aimed at reparation for their victims.

xi The Spanish system of parole is one of the most rigorous within the European Union (see a general comparison of the penitentiary systems in: Van Zyl Smit-Dünkel, 2001). 